\title{
The Association of vitamin D status and fasting glucose according to body fat mass in young healthy Thais
}

\author{
Hataikarn Nimitphong ${ }^{*}$, La-or Chailurkit, Suwannee Chanprasertyothin, Piyamitr Sritara \\ and Boonsong Ongphiphadhanakul
}

\begin{abstract}
Background: Existing inconclusive data on the relationship between vitamin D status and human glucose homeostasis suggests that other factors, such as adiposity, might influence this relationship. The present study aimed to investigate the association between 25-hydroxyvitamin D $[25(\mathrm{OH}) \mathrm{D}]$ and fasting plasma glucose (FPG) in the context of different amounts of total body fat in a healthy community-based population in Bangkok, Thailand.

Methods: This cross-sectional study was a part of health survey of employees of the Electricity Generating Authority of Thailand. There were 1,990 healthy subjects $(72.8 \%$ male) in this study. Total body fat was measured by bioelectrical impedance analysis. Total serum $25(\mathrm{OH}) \mathrm{D}, 25(\mathrm{OH}) \mathrm{D}_{3}$ and $25(\mathrm{OH}) \mathrm{D}_{2}$ were measured by LC-MS/MS.

Results: Age $(r=0.134, p<0.001)$ and FPG $(r=0.089, p<0.001)$ were positively correlated with $25(\mathrm{OH}) \mathrm{D}$ levels, while total body fat mass $(r=-0.049, p=0.03)$ were negatively correlated with $25(\mathrm{OH}) \mathrm{D}$ levels. $25(\mathrm{OH}) \mathrm{D}$ levels were higher in males than in females $(65.0 \pm 0.5$ vs. $53.5 \pm 0.5 \mathrm{nmol} / \mathrm{L}, p<0.001)$. After controlling for age, gender and total fat mass, FPG was no longer correlated with 25(OH)D. However, when subjects were stratified according to fat-free mass tertiles and controlled for age and gender, there was a positive, although weak association between $25(\mathrm{OH}) \mathrm{D}$ levels and FPG $(p=0.01)$ in the lowest tertile.
\end{abstract}

Conclusions: We therefore speculate that adiposity might influence the relationship of vitamin D status and FPG.

Keywords: 25-hydroxyvitamin D, Fasting plasma glucose, Total body fat mass, Adiposity

\section{Background}

In addition to its established role in calcium and bone metabolism, vitamin D possesses numerous other biological functions $[1,2]$. With regard to glucose homeostasis, it has been shown that vitamin $\mathrm{D}$ affects pancreatic beta-cell proliferation and survival $[3,4]$. It has also been demonstrated that vitamin D improves insulin sensitivity $[5,6]$. At the population level, several association studies have demonstrated a relationship between impaired vitamin D status and higher risk of prevalence as well as incidence of diabetes [7-9], although these findings are not undisputed. We found in a recent study of subjects from the $4^{\text {th }}$ Thai National Health Examination Survey (2,641 adults, aged $15-98)$ that low $25(\mathrm{OH}) \mathrm{D}_{3}$ but not $25(\mathrm{OH}) \mathrm{D}_{2}$ level was

\footnotetext{
* Correspondence: hataikarnn@hotmail.com

Faculty of Medicine, Ramathibodi Hospital, Mahidol University, Rama 6 Rd., Rajthevi, Bangkok 10400, Thailand
}

(c) 2013 Nimitphong et al.; licensee BioMed Central Ltd. This is an Open Access article distributed under the terms of the only in the subgroup of urban elderly ( $\geq 70$ years old) [10]. It is thus likely that if vitamin D does indeed affect glucose homeostasis, its influence is probably minute and there may be other interacting factors, for example body mass index (BMI), which cause results from population studies to be less consistent. Studies in vitamin D receptor (VDR) knockout mice revealed a lean phenotype resistant to dietinduced obesity [11,12], suggesting that vitamin D may have a role in promoting adipose tissue development in an in vivo context. Because low vitamin D status is associated with human obesity [13-15], it is possible that vitamin D action in adipose tissue underlies the relationship between vitamin $\mathrm{D}$ and glucose homeostasis in humans. The aim of this study is to explore the relationship between $25(\mathrm{OH}) \mathrm{D}$, a marker of vitamin $\mathrm{D}$ status, and fasting plasma glucose (FPG) in the context of different amounts \\ C Biomed Central}


of total body fat in a healthy community-based population in Bangkok, Thailand. The secondary objective is to investigate the association between 25(OH)D and FPG in subgroups of subjects stratified by gender and age.

\section{Methods}

This study was part of a health survey of 1,990 employees of the Electricity Generating Authority of Thailand (EGAT). Institutional Review Board approval was obtained prior to the commencement of the study, and all subjects gave informed consent. Described in detail elsewhere [16], survey data was collected by using self-administered questionnaires, physical examinations, electrocardiography, chest radiography, and blood analysis. Anthropometric variables including weight, height and waist circumferences were measured using standard techniques in all subjects [17]. Waist circumference was measured at the midway between the last rib and the iliac crest [17]. BMI was derived by weight $(\mathrm{kg}) /$ height $(\mathrm{m})^{2}$. Body composition was determined after at least $3 \mathrm{~h}$ of fasting using multifrequency bioelectrical impedance analysis with eight-point tactile electrodes (InBody 720; Biospace, Seoul, Korea). Fasting blood samples were obtained and sent for laboratory analysis of fasting plasma glucose (FPG) and 25(OH)D measurements. The study was approved by the IRB of Ramathibodi hospital, Mahidol University.

\section{Serum 25-hydroxyvitamin D [25(OH)D] measurement}

Serum $25(\mathrm{OH}) \mathrm{D}_{2}$ and $25(\mathrm{OH}) \mathrm{D}_{3}$ were analyzed by LC-MS/ MS with an Agilent 1200 Infinity liquid chromatograph (Agilent Technologies, Waldbronn, Germany) coupled to a QTRAP 5500 tandem mass spectrometer (AB SCIEX, Framingham MA, USA) using a MassChrom 25-OHVitamin $\mathrm{D}_{3} / \mathrm{D}_{2}$ diagnostics kit (ChromSystems, Munich, Germany). The summation of serum $25(\mathrm{OH}) \mathrm{D}_{2}$ and 25 $(\mathrm{OH}) \mathrm{D}_{3}$ [total $25(\mathrm{OH}) \mathrm{D}$ ] was used to reflect vitamin $\mathrm{D}$ status. Vitamin D deficiency was defined as having $25(\mathrm{OH}) \mathrm{D}$ levels of less than $50 \mathrm{nmol} / \mathrm{L}$ [18]. The interassay and intra-assay coefficients of variation of total serum $25(\mathrm{OH}) \mathrm{D}$ level were $6.3 \%$ and $5.0 \%$, respectively.

\section{Statistical analysis}

Data were expressed as mean \pm standard error of the mean (SEM). All data were normally distributed. Differences between two groups were assessed by Student's $t$-test. The correlations between dependent and independent variables were tested with Pearson correlation. Multiple linear regression analysis was performed to identify the association between FPG (the dependent variable) and $25(\mathrm{OH})$ $\mathrm{D}$ in each subgroup, stratified by gender (male vs. female), age (25-34, 35-44 and 45-54 years) and tertile of total body fat. A $p$ value less than 0.05 was considered statistically significant. All analyses were performed using the SPSS statistical software package, version 17.0 (SPSS Inc., Chicago IL, USA).

\section{Results}

Table 1 demonstrates the clinical characteristics of the study population. Subjects were mostly males $(n=1,449$, $72.8 \%$ ) because of the demographic structure of EGAT. A data comparison between males and females revealed that males were slightly older, had significantly higher BMI, waist circumference (WC), fasting plasma glucose (FPG) and muscle mass, and significantly lower total body fat mass.

With regard to vitamin D status, mean total 25(OH)D concentrations were significantly higher in males than in females $(65.0 \pm 0.5$ vs. $53.5 \pm 0.5 \mathrm{nmol} / \mathrm{L}, P<0.001)$. The dominant form of total $25(\mathrm{OH}) \mathrm{D}$ in this population group was $25(\mathrm{OH}) \mathrm{D}_{3}$. As expected, females had a higher prevalence of vitamin D deficiency: $43.1 \%$ of females had $25(\mathrm{OH}) \mathrm{D}$ less than $50 \mathrm{nmol} / \mathrm{L}$, whereas $13.9 \%$ of males were classified as vitamin D deficient (Table 1). Only 3 of

Table 1 Clinical characteristics of the study population

\begin{tabular}{|c|c|c|c|}
\hline Parameters & Male $n=1,449$ & Female $n=541$ & $P$ value \\
\hline Age (years) & $40.1 \pm 0.2(25-54)$ & $39.5 \pm 0.3(25-54)$ & 0.05 \\
\hline BMI $\left(\mathrm{kg} / \mathrm{m}^{2}\right)$ & $24.5 \pm 0.1(15-48)$ & $22.0 \pm 0.2(15-39)$ & $<0.001$ \\
\hline Waist circumference (WC) (cm) & $88.8 \pm 0.2(54-149)$ & $78.0 \pm 0.4(57-112)$ & $<0.001$ \\
\hline Fasting plasma glucose (FPG) (mmol/L) & $5.2 \pm 0.0(4-17.8)$ & $4.9 \pm 0.0(3.7-17.2)$ & $<0.001$ \\
\hline Muscle mass (kg) & $29.4 \pm 0.1(18.4-44.4)$ & $19.7 \pm 0.1(13.4-29.0)$ & $<0.001$ \\
\hline Total body fat mass (kg) & $17.6 \pm 0.2(2.9-68.1)$ & $18.3 \pm 0.3(6.8-46.4)$ & 0.04 \\
\hline Percent body fat (\%) & $24.5 \pm 0.2(6.7-46.7)$ & $32.5 \pm 0.3(16.9-51.1)$ & $<0.001$ \\
\hline \multicolumn{4}{|l|}{ Vitamin D status } \\
\hline$<50 \mathrm{nmol} / \mathrm{L}(\mathrm{n}=433)$ & $44 \pm 0.5(n=201)$ & $42 \pm 0.5(n=233)$ & 0.001 \\
\hline$\geq 50 \mathrm{nmol} / \mathrm{L}(\mathrm{n}=1,592)$ & $68.5 \pm 0.5(n=1,248)$ & $62.2 \pm 0.5(n=308)$ & $<0.001$ \\
\hline
\end{tabular}

Data is expressed as mean \pm SEM (range).

Body composition was assessed by bioelectrical impedance analysis (BIA). 
subjects, 1 male and 2 females, had 25(OH)D levels less than $25 \mathrm{nmol} / \mathrm{L}$.

Univariate analyses revealed that age $(r=0.134, p<$ $0.001)$, FPG $(r=0.089, p<0.001)$ and total body fat mass $(r=-0.049, p=0.027)$ were significantly, although weakly correlated with $25(\mathrm{OH}) \mathrm{D}$ levels. When classified subjects into 3 groups according to fat mass tertiles, a positive association between 25(OH)D and FPG was consistently found across 3 groups, but reached statistically significance only in the lowest tertile group (Figure 1). Multiple linear regression analysis showed that age, gender and total body fat mass, but not $25(\mathrm{OH}) \mathrm{D}$, were independently correlated with FPG. However, when subjects were stratified according to fat mass tertiles and that the analysis was controlled for age and gender, it was found that there was a significant association $(p=0.01)$, although a weak positive correlation $(r=0.097)$, between $25(\mathrm{OH}) \mathrm{D}$ levels and FPG only in the lowest tertile group, as shown in Table 2. Nevertheless, no relationship between 25(OH)D and FPG was detected when subjects were stratified according to age group (controlled for gender and body fat mass) or gender (controlled for age and body fat mass) (Table 2).

\section{Discussion}

There is increasing evidence that vitamin D status may modify the risk of type 2 diabetes. Most of the studies looking into the relationship between $25(\mathrm{OH}) \mathrm{D}$ levels or vitamin D supplementation and FPG, glucose homeostasis or incidence of new onset of type 2 diabetes have been performed in Caucasian populations [7-9]. The difference of this relationship between Caucasians and Asians has not been well recognized. In the present study, no association was demonstrated between vitamin $\mathrm{D}$ status and FPG. The same finding was reported in a study of 380 Malay adults (mean age of 48.5 years; $42 \%$ male). Investigators classified subjects into two groups, vitamin D insufficient $[25(\mathrm{OH}) \mathrm{D}$ levels $<50 \mathrm{nmol} / \mathrm{L}]$ and vitamin $\mathrm{D}$ sufficient [25(OH)D levels $\geq 50 \mathrm{nmol} / \mathrm{L}]$, and found no correlation between 25(OH)D levels and FPG [19]. On the other hand, in the Fourth Korea National Health and Nutrition Examination Survey $(n=5,787$; mean age of 48.5 (male) and 49.1 (female) years; $42 \%$ male), 25(OH)D levels were inversely associated with FPG after adjusting for age and sex [20]. This was in accordance with the findings in a study of 3,262 elderly Chinese (age 50-70 years; $44 \%$ male), where $25(\mathrm{OH}) \mathrm{D}$ levels were negatively associated with FPG after controlling for age, sex and BMI [21]. Differences in study results can be partly explained by different subject characteristics, i.e. the subjects in our study were relatively young and predominantly male.

In this study, we also confirmed a negative correlation between $25(\mathrm{OH}) \mathrm{D}$ and degree of adiposity as defined by BMI, WC (data not shown) and total body mass. The
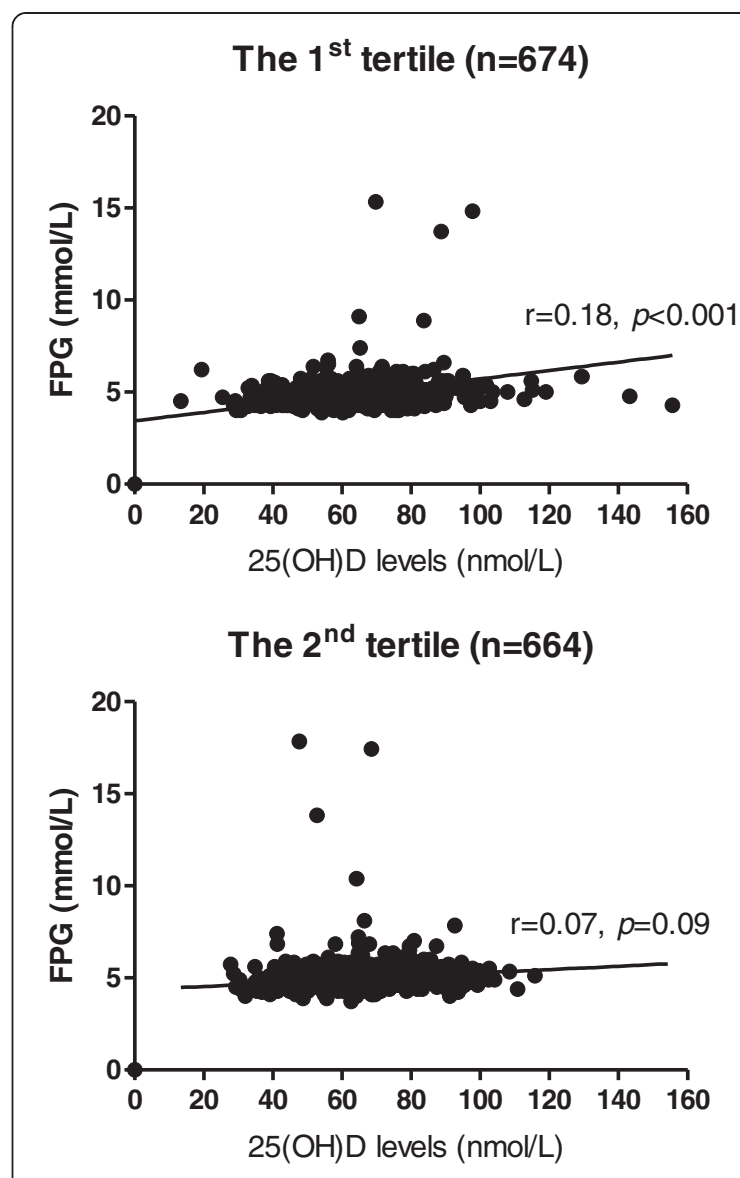

The $3^{\text {rd }}$ tertile $(n=652)$

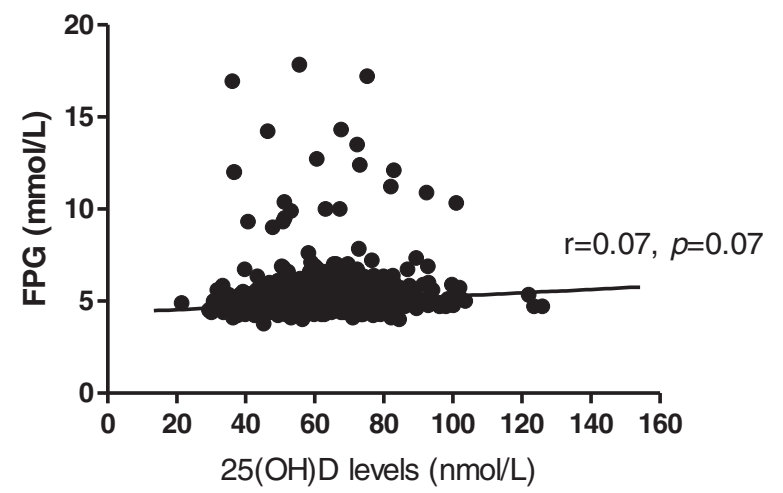

Figure 1 Scatter plots of fasting plasma glucose and total 25(OH)D according to body fat mass tertiles.

predominant source of vitamin D in these subjects was from sun exposure. It has been reported that with a similar amount of 7-dehydrocholesterol in the epidermis and using a similar amount of UVB irradiation, serum vitamin $\mathrm{D}_{3}$ levels of obese subjects were $50 \%$ lower than those of non-obese subjects; this suggested the possibility of sequestration of vitamin D in expanded adipose tissue [22]. In a hypocaloric intervention study, with $10 \%$ weight loss 
Table 2 Adjusted association of serum FPG and 25(OH)D stratified by gender, age range and tertile of total body fat

\begin{tabular}{|c|c|c|c|}
\hline Parameters & $\begin{array}{c}25(\mathrm{OH}) \mathrm{D} \\
\text { levels (nmol/L) }\end{array}$ & $\begin{array}{l}\text { Standardized } \\
\text { coefficients }(\beta)\end{array}$ & $P$ value \\
\hline \multicolumn{4}{|l|}{ Gender $^{1}$} \\
\hline Male $(n=1,449)$ & $65 \pm 0.5$ & 0.031 & 0.25 \\
\hline Female $(n=541)$ & $53.5 \pm 0.5$ & 0.042 & 0.35 \\
\hline \multicolumn{4}{|l|}{$\begin{array}{l}\mathbf{A g e}^{\mathbf{2}} \\
{[\mathrm{n}, \text { range of age (years)] }}\end{array}$} \\
\hline $\begin{array}{l}\text { group } 1(n=402, \text { age } \\
25-34)\end{array}$ & $58.5 \pm 0.8$ & 0.023 & 0.64 \\
\hline $\begin{array}{l}\text { group } 2(n=1,064, \text { age } \\
35-44)\end{array}$ & $62.5 \pm 0.5$ & 0.044 & 0.13 \\
\hline $\begin{array}{l}\text { group } 3(n=524, \text { age } \\
44-54)\end{array}$ & $63.8 \pm 0.8$ & 0.039 & 0.36 \\
\hline \multicolumn{4}{|l|}{$\begin{array}{l}\text { Total body fat mass }{ }^{3} \\
{[\text { mean } \pm \text { SEM; range }(\mathrm{kg})]}\end{array}$} \\
\hline $\begin{array}{l}1^{\text {st }} \text { tertile }(n=674) \\
(11.5 \pm 0.1 ; 2.9-14.5)\end{array}$ & $62.5 \pm 0.8$ & 0.097 & 0.01 \\
\hline $\begin{array}{l}2^{\text {nd }} \text { tertile }(n=664) \\
(17.0 \pm 0.1 ; 14.6-19.5)\end{array}$ & $62.3 \pm 0.5$ & -0.013 & 0.73 \\
\hline $\begin{array}{l}3^{\text {rd }} \text { tertile }(n=652) \\
(25.1 \pm 0.2 ; 19.6-68.1)\end{array}$ & $61 \pm 0.5$ & 0.025 & 0.51 \\
\hline
\end{tabular}

Data is expressed as mean \pm SEM

${ }^{1}$ controlled for age and body fat mass; ${ }^{2}$ controlled for gender and body fat mass; ${ }^{3}$ controlled for age and gender.

$25(\mathrm{OH}) \mathrm{D}$ levels increased by $34 \%$ without any changes in vitamin D intake [23]. It is also conceivable that reducing fat mass may somehow influence the metabolism of vitamin D and some of its effects.

In contrast to the results of a previous study in Thailand [10], which demonstrated an association between lower vitamin $\mathrm{D}$ status and an increased risk of diabetes in subgroup of older subjects residing in urban areas, the present study reported the reversed direction of the relationship in the younger age group. A statistical interaction was also demonstrated between body fat mass, vitamin $\mathrm{D}$ status and FPG. In the lowest tertile of body fat mass subgroups, the higher the participants' $25(\mathrm{OH}) \mathrm{D}$ levels, the higher their FPG; this was in contrast to previous studies in both Caucasians and Asians [20,21], where the results showed an opposite trend. Although the strength of the statistical association was relatively weak and the underlying basis unclear, the finding is intriguing. In spite of the fact that most epidemiologic studies demonstrated lower circulating vitamin $\mathrm{D}$ is generally associated with increased adiposity [24], underlined mechanism of the association has not been well established. Nevertheless, the mechanistic studies of this correlation in mouse model are complex. For example VDR knockout mice were lean [11]. The same study also demonstrated an increase in uncoupling protein (UCP), a marker of brown adipose tissue [11].
The main function of brown adipose tissue is to regulate thermogenesis by expressing UCPs that separate oxidative phosphorylation from ATP (adenosine triphosphate) production, producing heat in place of ATP [25]. Confirmatory data from a recent study of overexpression of VDR in mice demonstrated an increase in fat mass, mainly due to markedly reduced energy expenditure. In addition, the expression of genes involved in the regulation of fatty acid transport, thermogenesis and lipolysis were suppressed in the transgenic mice [25]. Taken together, these data confirm an important role of VDR in the regulation of energy metabolism. Brown adipose tissue has recently been confirmed to be functionally active in human adults [26], and is likely to decrease with age [26]. It is therefore conceivable that in younger adults, who may possess a higher amount of brown adipose tissue, vitamin D may have a greater influence in inhibiting the function of brown adipose tissue rather than in inhibiting lipogenesis and its metabolic consequences in white adipose tissue. Further studies to explore the comparative effects of vitamin D on brown and white adipose tissues are warranted.

If vitamin D does indeed increase FPG, it remains unclear whether it would increase diabetes risk and diabetic complications. Although FPG is generally used for the diagnosis of diabetes [27], it has been recognized that its relationship to diabetic complications may not be straightforward. For example, MODY (maturity onset diabetes of the young) patients with mutation in the glucokinase gene presented with elevated FPG but generally without a significant increase in average HbA1c and diabetes-related complications [28]. Further studies to clarify the issue, using measures more directly related to diabetes complications, are therefore warranted. One of the limitation of this study is we could only assess FPG (single measurement) and did not examine other metabolic measurement such as HbA1c, fasting insulin, lipid profile. We did not have data about previous history of diabetes or metabolic syndrome in our study subjects. Nonetheless, statistical analysis which including or excluding subjects who had FPG $\geq 7 \mathrm{mmol} / \mathrm{L}(126 \mathrm{mg} / \mathrm{dL})$ provided the same results. In addition, other measures that can potentially affect both diabetic risk and vitamin D such as calcium were not evaluated.

\section{Conclusion}

In conclusion our findings were contrary to those of most studies, where a relationship between vitamin D status and diabetes has been demonstrated. Although the present findings need to be replicated in separate populations, they suggest the heterogeneity of the effect of vitamin D status based on interacting factors such as body fat mass; this may underlie the inconsistent results among previously performed studies. 


\section{Competing interests}

The authors affirm they have no competing interests.

\section{Authors' contributions}

$\mathrm{HN}$ and $\mathrm{BO}$ conceived of the study, participated in its design and coordination, performed the statistical analysis and helped to draft the manuscript. LC carried out the vitamin D metabolites measurement (LC-MS/ MS). SC carried out the biochemical measurement. PS participated in its design and coordination. All authors read and approved the final manuscript.

\section{Acknowledgments}

Address all correspondence and requests for reprints to: Hataikarn Nimitphong, M.D., at the Faculty of Medicine, Ramathibodi Hospital, Rama 6 Rd., Rajthevi, Bangkok 10400, Thailand; e-mail: hataikarnn@hotmail.com. This study was supported by the Thailand Research Fund and Mahidol University.

Received: 28 August 2013 Accepted: 20 December 2013 Published: 27 December 2013

\section{References}

1. Adams JS, Hewison M: Update in vitamin D. J Clin Endocrinol Metab 2010, 95(2):471-478.

2. Holick MF: Vitamin D: extraskeletal health. Endocrinol Metab Clin North Am 2010, 39(2):381-400. table of contents.

3. Johnson JA, Grande JP, Roche PC, Kumar R: Immunohistochemical localization of the 1,25(OH)2D3 receptor and calbindin D28k in human and rat pancreas. Am J Physiol 1994, 267(3 Pt 1):E356-E360.

4. Kadowaki S, Norman AW: Pancreatic vitamin D-dependent calcium binding protein: biochemical properties and response to vitamin D. Arch Biochem Biophys 1984, 233(1):228-236.

5. von Hurst PR, Stonehouse W, Coad J: Vitamin D supplementation reduces insulin resistance in South Asian women living in New Zealand who are insulin resistant and vitamin $\mathrm{D}$ deficient - a randomised, placebo-controlled trial. Br J Nutr 2010, 103(4):549-555.

6. Pittas AG, Harris SS, Stark PC, Dawson-Hughes B: The effects of calcium and vitamin $\mathrm{D}$ supplementation on blood glucose and markers of inflammation in nondiabetic adults. Diabetes Care 2007, 30(4):980-986.

7. Alvarez JA, Ashraf A: Role of vitamin d in insulin secretion and insulin sensitivity for glucose homeostasis. Int J Endocrinol 2010:351385.

8. Mitri J, Muraru MD, Pittas AG: Vitamin D and type 2 diabetes: a systematic review. Eur J Clin Nutr 2011, 65(9):1005-1015.

9. Pittas AG, Nelson J, Mitri J, Hillmann W, Garganta C, Nathan DM, Hu FB, Dawson-Hughes B: Plasma 25-hydroxyvitamin D and progression to diabetes in patients at risk for diabetes: an ancillary analysis in the Diabetes Prevention Program. Diabetes Care 2012, 35(3):565-573.

10. Chailurkit LO, Aekplakorn W, Ongphiphadhanakul B: The association between vitamin $D$ status and type 2 diabetes in a Thai population, a cross-sectional study. Clin Endocrinol (Oxf) 2012, 77(5):658-664.

11. Narvaez CJ, Matthews D, Broun E, Chan M, Welsh J: Lean phenotype and resistance to diet-induced obesity in vitamin $D$ receptor knockout mice correlates with induction of uncoupling protein-1 in white adipose tissue. Endocrinology 2009, 150(2):651-661.

12. Wong KE, Szeto FL, Zhang W, Ye H, Kong J, Zhang Z, Sun XJ, Li YC: Involvement of the vitamin $D$ receptor in energy metabolism: regulation of uncoupling proteins. Am J Physiol Endocrinol Metab 2009, 296(4):E820-E828.

13. Lenders CM, Feldman HA, Von Scheven E, Merewood A, Sweeney C, Wilson DM, Lee PD, Abrams SH, Gitelman SE, Wertz MS, Klish WJ, Taylor GA, Chen TC, Holick MF, Elizabeth Glaser Pediatric Research Network Obesity Study Group: Relation of body fat indexes to vitamin $D$ status and deficiency among obese adolescents. Am J Clin Nutr 2009, 90(3):459-467.

14. Looker AC, Pfeiffer CM, Lacher DA, Schleicher RL, Picciano MF, Yetley EA: Serum 25-hydroxyvitamin D status of the US population: 1988-1994 compared with 2000-2004. Am J Clin Nutr 2008, 88(6):1519-1527.

15. Valina-Toth AL, Lai Z, Yoo W, Abou-Samra A, Gadegbeku CA, Flack JM: Relationship of vitamin $\mathrm{D}$ and parathyroid hormone with obesity and body composition in African Americans. Clin Endocrinol (Oxf) 2010, 72(5):595-603.

16. Vathesatogkit P, Woodward M, Tanomsup S, Hengprasith B, Aekplakorn W, Yamwong S, Sritara P: Long-term effects of socioeconomic status on incident hypertension and progression of blood pressure. $J$ Hypertens 2012, 30(7):1347-1353.
17. Vathesatogkit P, Woodward M, Tanomsup S, Ratanachaiwong W, Vanavanan S, Yamwong S, Sritara P: Cohort profile: the electricity generating authority of Thailand study. Int J Epidemiol 2012, 41(2):359-365.

18. Institute of Medicine: Dietary reference intakes for calcium and vitamin D. Washington, DC: National Academy of Science; 2011.

19. Moy FM, Bulgiba A: High prevalence of vitamin D insufficiency and its association with obesity and metabolic syndrome among Malay adults in Kuala Lumpur, Malaysia. BMC Public Health 2011, 11:735.

20. Choi HS, Kim KA, Lim CY, Rhee SY, Hwang YC, Kim KM, Kim KJ, Rhee Y, Lim SK: Low serum vitamin $D$ is associated with high risk of diabetes in Korean adults. J Nutr 2011, 141(8):1524-1528.

21. Lu L, Yu Z, Pan A, Hu FB, Franco OH, Li H, Li X, Yang X, Chen Y, Lin X: Plasma 25-hydroxyvitamin D concentration and metabolic syndrome among middle-aged and elderly Chinese individuals. Diabetes Care 2009, 32(7):1278-1283.

22. Wortsman J, Matsuoka LY, Chen TC, Lu Z, Holick MF: Decreased bioavailability of vitamin D in obesity. Am J Clin Nutr 2000, 72(3):690-693.

23. Tzotzas T, Papadopoulou FG, Tziomalos K, Karras S, Gastaris K, Perros P, Krassas GE: Rising serum 25-hydroxy-vitamin D levels after weight loss in obese women correlate with improvement in insulin resistance. J Clin Endocrinol Metab 2010, 95(9):4251-4257.

24. Chacko SA, Song Y, Manson JE, Van Horn L, Eaton C, Martin LW, McTiernan A, Curb JD, Wylie-Rosett J, Phillips LS, Plodkowski RA, Liu S: Serum 25-hydroxyvitamin D concentrations in relation to cardiometabolic risk factors and metabolic syndrome in postmenopausal women. Am J Clin Nutr 2011, 94(1):209-217.

25. Wong KE, Kong J, Zhang W, Szeto FL, Ye H, Deb DK, Brady MJ, Li YC: Targeted expression of human vitamin $D$ receptor in adipocytes decreases energy expenditure and induces obesity in mice. $J$ Biol Chem 2011, 286(39):33804-33810.

26. Cypess AM, Lehman S, Williams G, Tal I, Rodman D, Goldfine AB, Kuo FC, Palmer EL, Tseng YH, Doria A, Kolodny GM, Kahn CR: Identification and importance of brown adipose tissue in adult humans. N Engl J Med 2009, 360(15):1509-1517.

27. Standards of medical care in diabetes. Diabetes Care 2012, 35(Suppl 1):S11-S63.

28. McDonald TJ, Ellard S: Maturity onset diabetes of the young: identification and diagnosis. Ann Clin Biochem 2013, 50(Pt 5):403-415.

\section{doi:10.1186/1472-6823-13-60}

Cite this article as: Nimitphong et al:: The Association of vitamin D status and fasting glucose according to body fat mass in young healthy Thais. BMC Endocrine Disorders 2013 13:60.

\section{Submit your next manuscript to BioMed Central and take full advantage of:}

- Convenient online submission

- Thorough peer review

- No space constraints or color figure charges

- Immediate publication on acceptance

- Inclusion in PubMed, CAS, Scopus and Google Scholar

- Research which is freely available for redistribution 